\title{
Finding balance between fire hazard reduction and erosion control in the Lake Tahoe Basin, California-Nevada
}

\author{
Nicolas M. Harrison ${ }^{\mathrm{a}, 1}$, Andrew P. Stubblefield ${ }^{\mathrm{a}, *}$, J. Morgan Varner $^{\mathrm{b}}$, Eric E. Knapp ${ }^{\mathrm{c}}$ \\ ${ }^{a}$ Department of Forestry and Wildland Resources, Humboldt State University, One Harpst St., Arcata, CA 95521, USA \\ ${ }^{\mathrm{b}}$ Department of Forest Resources \&' Environmental Conservation, Virginia Tech, Blacksburg, VA 24061, USA \\ ' USDA Forest Service, Pacific Southwest Research Station, 3644 Avtech Parkway, Redding, CA 96002, USA
}

\section{A R T I C L E I N F O}

\section{Article history:}

Received 14 July 2015

Received in revised form 16 October 2015

Accepted 16 October 2015

Available online 24 October 2015

\section{Keywords:}

Fuels management

Mastication

Prescribed fire

Runoff simulation

Snowmelt

\begin{abstract}
A B S T R A C T
The 2007 Angora Fire served as a stark reminder of the need for fuel reduction treatments in the Lake Tahoe Basin, California-Nevada, USA. Concerns exist, however, that the corresponding removal of forest floor fuels could increase erosion rates, negatively affecting the clarity of Lake Tahoe. To quantify tradeoffs between fuel reduction and erosion, we conducted field-based snowmelt runoff simulation experiments at 16 sites within the Lake Tahoe Basin that had received mechanical mastication or prescribed fire treatments. Erodibility was measured to determine if thresholds of litter, duff, and woody fuel cover could be established that are sufficient for trapping sediment and increasing infiltration, without contributing to fire hazard. Field snow-melt simulations revealed that as little as $25 \%$ of the ground surface covered with masticated fuels over duff was sufficient to mitigate erosion. The post-prescribed fire environment characterized by heterogeneous patches of exposed bare mineral soil interspersed with unburned patches mitigated erosion by increasing infiltration. Considerable increases in sediment yield were observed in plots with $>35 \%$ of ground area burned; the highest total sediment yields (values) occurred in plots where between $66 \%$ and $100 \%$ of the soil surface burned. Our field results suggest that erosion and wildfire severity can be simultaneously mitigated through the use of masticated fuel reduction treatments or prescribed fire treatments that leave sufficient organic matter to trap sediment but have sufficiently low fuel loading and/or enough fuel discontinuity or patchiness to limit fire spread.
\end{abstract}

(c) 2015 Elsevier B.V. All rights reserved.

\section{Introduction}

Restoring ecosystem structure, composition, and function while reducing fire hazard are primary goals of land management in many fire-prone landscapes worldwide (Allen et al., 2002; Stephens et al., 2012; Ryan et al., 2013). In dry western North American forests and woodlands, these treatments often focus on modifying overstory structure and surface woody fuel to diminish fireline intensity, crown ignition, and canopy fire spread (Agee and Skinner, 2005). The unintended consequences of fuels treatments for wildlife habitat, plant community composition, non-native species spread, and erosion are often overlooked (Hunter et al., 2006). Hillslope runoff from disturbed soils in burned landscapes is a

\footnotetext{
* Corresponding author.

E-mail addresses: nharrison@hrclllc.com (N.M. Harrison), Andrew.Stubblefield@ humboldt.edu (A.P. Stubblefield), mvarner@vt.edu (J.M. Varner), eknapp@fs.fed.us (E.E. Knapp).

${ }^{1}$ Present address: Humboldt Redwood Company, 125 Main Street, Scotia, CA 95565, USA.
}

major concern for land managers because fine suspended particles transport nutrients that contribute to eutrophication and losses in clarity of receiving water bodies (Goldman et al., 1989).

Efforts to minimize wildfire hazard can oftentimes conflict with those meant to reduce the potential for erosion (Shakesby et al., 1993). Woody fuels and litter limit erosion by protecting the soil from rainsplash, reducing the occurrence of overland flow processes, trapping sediment passing over the soil surface, impeding the formation of rills, and increasing infiltration rates (Robichaud, 2000). Litter, duff, and down woody materials can reduce turbidity, erosion rates, and sediment yields (MacDonald and Stednick, 2003; Robichaud et al., 2010). A continuous cover of surface fuels provides the greatest opportunity to minimize the potential for erosion. However, distributing surface fuel cover evenly over the landscape leads to fuel continuity which also increases the potential fire hazard. Ironically, failing to reduce fire hazard can result in severe erosion when wildfire ultimately occurs (Silins et al., 2009).

We hypothesize that the solution to this apparent paradox can be found through mimicking the patchy burn mosaic of historic fire 
regimes in any fuel reduction treatment, including prescribed burning or mastication (Fig. 1). There is evidence that historical Sierra Nevadan mixed-conifer forests reflected this desirable spatial heterogeneity and forest floor fuel discontinuity (Taylor, 2004; Knapp and Keeley, 2006; Rocca, 2009). Fires occurred frequently in the Sierras, resulting in relatively low fuel loads and discontinuous fuels, (Show and Kotok, 1924) producing patchy burns and reinforcing heterogeneity in fire severity. A century of fire exclusion has resulted in fuel continuity and forest types prone to severe wildfire that are uniformly intense over large spatial scales (Miller and Urban, 2000; Allen et al., 2002; Schoennagel et al., 2004; Hessburg et al., 2005; Knapp et al., 2005; Donovan and Brown, 2007). The absence of conditions conducive to burn patchiness in contemporary forests limits the formation of unburned islands of groundcover that serve to slow erosion and increase infiltration of runoff (Martin and Sapsis, 1992). Rainfall simulation experiments conducted by Johansen et al. (2001) indicated that post-fire sediment yields increased dramatically when percent bare soil exceeded a threshold of $70 \%$.

We designed an experiment to test this "patchy burn" hypothesis, with fuel reduction treatments spanning a range of bare soil and groundcover to better understand thresholds for optimizing both erosion control and reduction of fire hazard. Field-based simulation of rill erosion resulting from snowmelt runoff was conducted within forested areas of the Lake Tahoe Basin treated with mechanical mastication and prescribed fire. Observed erosion characteristics (sediment yields, particle diameters, and infiltration percentages) were correlated with detailed site depictions (fuel bed characteristics, soil properties, and slope steepness), to determine optimal levels of surface fuel retention for mechanical mastication and prescribed fire treatments.

\section{Materials and methods}

\subsection{Study site}

The study was performed at Lake Tahoe, California-Nevada, USA, where these erosion and fire management issues have great relevance. Over the past 25 years, slowing or reversing the loss of clarity of the lake ( $-30 \%$ over three decades) has become an issue of primary importance (Jassby et al., 1994; Swift et al., 2005; Grismer and Ellis, 2006). The social and economic priority of these efforts is rivaled only by the necessity to mitigate effects of wildland fire. The 2007 Angora Fire in South Lake Tahoe, CA burned 1254 ha of mixed-conifer forest, destroyed 254 residential and 75 commercial structures, and led to firefighting costs that exceeded US \$11 million (Safford et al., 2009; California Department of Forestry and Fire Protection, 2011). The rapid spread of this wildfire was due in part to fuels that had accumulated in the absence of periodic fire (Safford et al., 2009).

The Lake Tahoe Basin is situated near the crest of the Sierra Nevada at an elevation of $1900 \mathrm{~m}$ above sea level at the lake and $2700 \mathrm{~m}$ at the crest (Coats et al., 1976). The majority of annual precipitation (average $=800 \mathrm{~mm}$ ) falls as snow between November and April (Western Regional Climate Center, 2010). Annual snowmelt primarily occurs in the late spring to early summer. Dramatic flood events occasionally occur when warm rains fall on the accumulated snow. Of the $1363 \mathrm{~km}^{2}$ Basin, $800 \mathrm{~km}^{2}$ is a forested watershed drained by 63 small streams, with the remainder lake surface (Fig. 2, Goldman, 1988). Lake Tahoe is a large, deep, oligotrophic, sub-alpine lake with a mean depth of $333 \mathrm{~m}$ (Gardner et al., 2000). The combination of great depth, small ratio of watershed to lake area, and granitic basin geology has produced a lake of extremely low fertility and high transparency (Jassby et al., 1994; Swift et al., 2005).

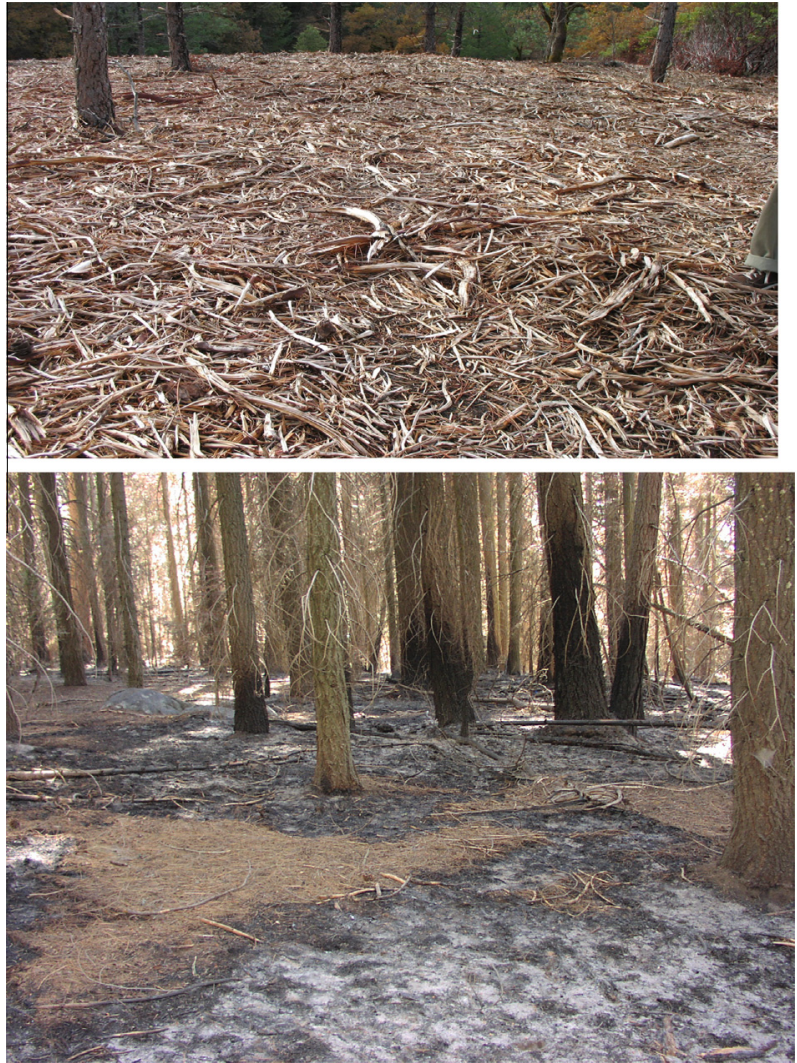

Fig. 1. Above: Mastication treatments in the Lake Tahoe Basin reduce stand density and produce a compact but continuous fuelbed (Photo: J. Kane). Below: Forest floor after an early-season prescribed burn in mixed conifer forest fuels similar to those found in the Lake Tahoe Basin.

This study focused on two fuels management approaches (prescribed fire and mechanical mastication) widely employed within the Lake Tahoe Basin and many other fire-prone western USA forests. Mastication is the process of mechanically converting live or dead standing biomass into surface fuel by chipping or breaking up larger pieces into smaller portions resulting in dense woody fuelbeds (Kane et al., 2009) (Fig. 1). Prescribed fire is the deliberate application of fire to forest fuels to meet a wide spectrum of management goals including reducing the intensity of subsequent wildfire (Wade and Lunsford, 1989; Ryan et al., 2013). These treatments are both effective at reducing fire hazard, but mastication results in a compact, relatively uniform layer of woody fuels while prescribed fire partially or fully consumes surface forest floor and woody fuels.

Research was conducted in 16 forested sites throughout the Basin, eight of which were positioned in areas where recent mastication treatments occurred (within the same season) and eight where prescribed fires occurred (Fig. 2 and Table 1). Sites were selected with moderate to steep slopes (15-48\%) typical for the Basin and steep enough for runoff to be potentially generated within plots. Research sites were all on common soil types within the Basin, broadly characterized as granitic, volcanic or a mixture of the two, with surface soil textures of cobbly or stony sandy loams and parent materials that included granite, granodiorite, metamorphics, and extrusive lavas (Naslas et al., 1994). All sites were dominated by a Sierran mixed-conifer forest consisting of Jeffrey pine (Pinus jeffreyi), ponderosa pine $(P$. ponderosa), sugar pine ( $P$. lambertiana), white fir (Abies concolor), red fir (A. magnifica), and incense-cedar (Calocedrus decurrens). Common shrub associates included huckleberry oak (Quercus vacciniifolia), greenleaf manzanita (Arctostaphylos patula), mountain whitethorn (Ceanothus cordulatus), and mountain sagebrush (Artemisia tridentata). 

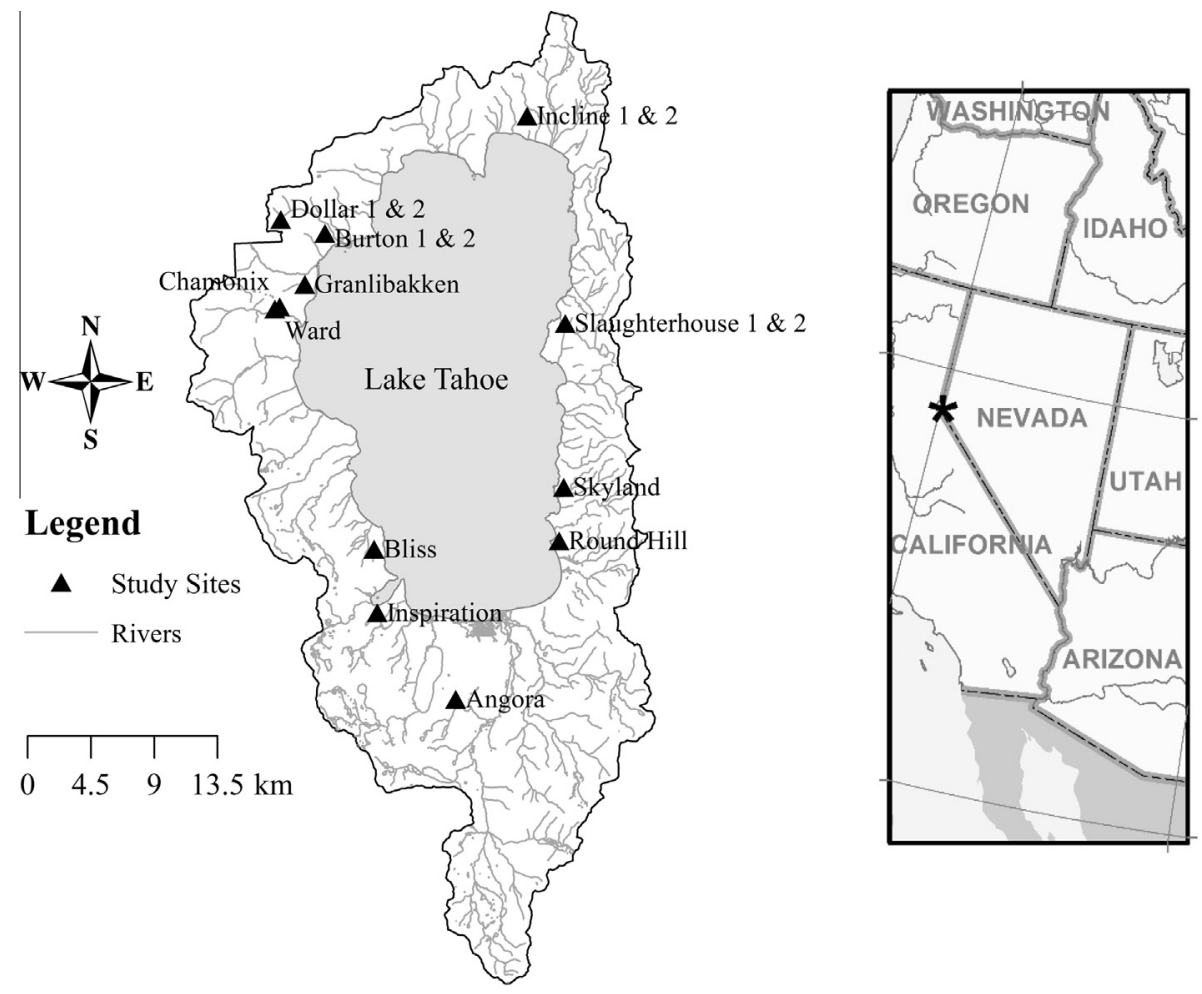

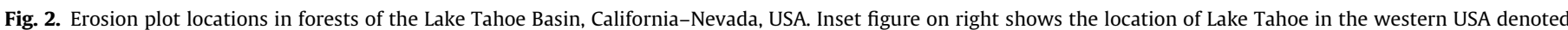
with an asterisk.

Table 1

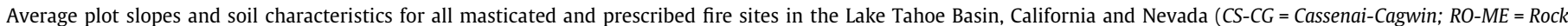
Outcrop-Meeks; DA-TE = Dagget-Tempo; PA-KN = Paige-Kneeridge; PM = Paige Medial; JO-TA = Jorge-Tahoma).

\begin{tabular}{|c|c|c|c|c|c|c|}
\hline Site & $\begin{array}{l}\text { Avg slope } \\
(\%)\end{array}$ & Soil type & Parent material & $\begin{array}{l}K^{\mathrm{b}} \\
\left(\mathrm{cm} \mathrm{s}^{-1}\right)\end{array}$ & $\begin{array}{l}\text { Infiltration }{ }^{c} \\
\left(\mathrm{~mL} \mathrm{~s}^{-1}\right)\end{array}$ & $\begin{array}{l}\text { Bulk density (field) } \\
\left(\mathrm{g} \mathrm{cm}^{-3}\right)\end{array}$ \\
\hline Skyland & 21 & CS-CG & Granitic & 0.002 & 0.399 & 1.38 \\
\hline Round Hill & 24 & $\mathrm{CS}-\mathrm{CG}$ & Granitic & 0.008 & 0.374 & 1.26 \\
\hline Angora & 15 & RO-ME & Granitic & $<0.001$ & 0.259 & 1.30 \\
\hline Bliss & 19 & $\mathrm{CS}-\mathrm{CG}$ & Granitic & 0.001 & 0.219 & 1.28 \\
\hline Inspiration & 24 & DA-TE & Granitic & 0.001 & 0.188 & 1.29 \\
\hline Ward & 27 & PA-KN & Volcanic & 0.002 & 0.140 & 1.21 \\
\hline Chamonix & 25 & $\mathrm{PM}$ & Volcanic & $<0.001$ & 0.049 & 0.81 \\
\hline Granlibakken $^{\mathrm{a}}$ & 25 & JO-TA & Volcanic & & & \\
\hline Incline 1 & 38 & JO-TA & Volcanic & 0.001 & & 0.89 \\
\hline Incline 2 & 38 & JO-TA & Volcanic & 0.001 & & 1.16 \\
\hline Burton 1 & 23 & JO-TA & Volcanic & 0.001 & & 0.77 \\
\hline Burton 2 & 23 & JO-TA & Volcanic & 0.001 & & 0.94 \\
\hline Slaughterhouse 1 & 35 & $\mathrm{CS}-\mathrm{CG}$ & Granitic & 0.001 & & 1.11 \\
\hline Slaughterhouse 2 & 34 & $\mathrm{CS}-\mathrm{CG}$ & Granitic & 0.006 & & 1.23 \\
\hline Dollar 1 & 28 & JO-TA & Volcanic & 0.003 & & 0.84 \\
\hline Dollar 2 & 24 & JO-TA & Volcanic & 0.001 & & 1.26 \\
\hline
\end{tabular}

a No soil samples were taken at Granlibakken.

b $K$ indicates hydraulic conductivity.

c Infiltration was measured at the prescribed fire sites but not the masticated fuel sites.

Rill erosion resulting from snowmelt runoff was simulated using $5 \times 2$ m erosion plots. Each plot contained a unique treatment with respect to thickness and spatial distribution of forest litter or masticated activity fuels. In masticated sites, treatments compared erosion potential in varying amounts of bare soil exposure (0-100\%) and in varying amounts of surface fuels $(0-100 \%)$. In prescribed fire sites, erosion potential was examined within plots characterized by varying degrees of fire severity, as categorized by forest floor fuel consumption (as measured by mineral soil exposure). Fire severity in the prescribed fire sites was categorized based on a point sampling method along each plot surface that estimated the bare mineral soil exposure (\%) and the distribution and depth of cover.
Soil sampling was carried out on all 16 sites to estimate bulk density, hydraulic conductivity, and volumetric water content prior to experiments. These data were collected through a geodetic sampling method based on methodologies described by Pennock et al. (2008). At each of five sample points per site, field bulk density, hydraulic conductivity, and volumetric water content were measured through the use of a field core-sampler, Mini-Disc Infiltrometer $^{2}$ (Decagon Devices, Inc., Pullman, WA) and a Hydrosense

\footnotetext{
${ }^{2}$ Mention of this product does not constitute endorsement by the U.S. Forest Service.
} 
Portable Moisture Probe ${ }^{2}$ (Campbell Scientific, Logan, UT), respectively. Hydraulic conductivity $(K)$ values and infiltration rates were measured at the soil surface and at $10 \mathrm{~cm}$ depths at all prescribed fire sites. Soils data were not collected at the Granlibakken site due to end of the field season time constraints.

\subsection{Plot design and characterization: Masticated sites}

Each $5 \times 2 \mathrm{~m}$ plot contained a fuel treatment in which masticated fuels were manipulated by varying either spatial distribution or thickness (=depth). The comparisons varying the spatial distribution of fuels were designed to evaluate what proportion of ground area covered by fuels is necessary to trap sediment contributed by the proportion of bare mineral soil area. Three treatments were created where surface fuel and duff were retained on (1) the lower $25 \%$ of the plot; (2) the lower $50 \%$ of the plot; and (3) the lower $75 \%$ of the plot (Fig. 3). These treatments were compared to two controls: (1) plots where $0 \%$ of surface fuel and duff were retained and (2) plots where surface fuel and duff remained undisturbed. The duff (fermentation and humus organic soil horizons) layer depth, litter depth, and surface fuel height of the masticated areas in each plot were measured at multiple sample points prior to fuel removal. These depths were totaled per plot, providing a means to evaluate the effectiveness that various organic horizon depths possess at infiltrating flows, trapping sediment, and mitigating any erosive processes produced by overland flow in the upslope patches of exposed soil.

Masticated treatment comparisons involving varying the thickness of fuels tested the amount of masticated fuel necessary to mitigate erosion without the aid of underlying litter and duff. All woody surface fuels in the $100 \%$ removal plots were collected, separated into size classes (timelag categories of $<0.64 \mathrm{~cm}, 0.65-$ $2.54 \mathrm{~cm}$, and $2.55-6.25 \mathrm{~cm}$ diameter), bagged, oven-dried and weighed. Four even retention plots were then created at each site to evaluate the relationship between woody fuel loading and sediment yield. After removing all surface fuel, litter, and duff, a proportion of the woody surface fuel was evenly redistributed across the bare mineral soil. The four treatments (Fig. 4) were $25 \%, 50 \%$, $75 \%$, and $100 \%$ of the woody surface fuel amount weighed in the $0 \%$ retention plot (the reference mass). Erosion in these four treatments was compared to the $0 \%$ retention plot (control).

While the fuel loading and depths varied among treatments, fuels were continuous in all treatments. Fuel depth (comprising the distance from the top of surface fuels to the top of the bare mineral soil) was measured after treatment creation but prior to the erosion simulations at multiple sample points within all even retention treatments.

\subsection{Plot design and characterization: Prescribed fire sites}

Six $5 \times 2$ meter plots that varied in fuel consumption and patchiness were established at each of the eight prescribed fire sites. The boundaries for each plot were selected to encompass spatial distributions of burn patchiness that represented potential treatment outcomes from low-intensity prescribed burns or pile burns where fire had been allowed to spread to litter and duff between the burn piles. Unlike plots in masticated sites, fuels located within prescribed fire plots were not manipulated. Two treatments served as controls on these sites: (1) one plot placed in a completely unburned area nearby and (2) one plot where $100 \%$ of available fuels were consumed by fire. Depending on site-specific burn patterns, the remaining four treatments were located in plots in areas where fire had consumed $0-25 \%, 25-50 \%, 50-75 \%$ or $75-100 \%$ of woody surface fuels, litter, and duff, exposing varying degrees of bare mineral soil.

The specific amount of bare mineral soil exposure and the distribution and depth of cover within each plot were estimated by a point quadrat method similar to the vegetation analysis procedure

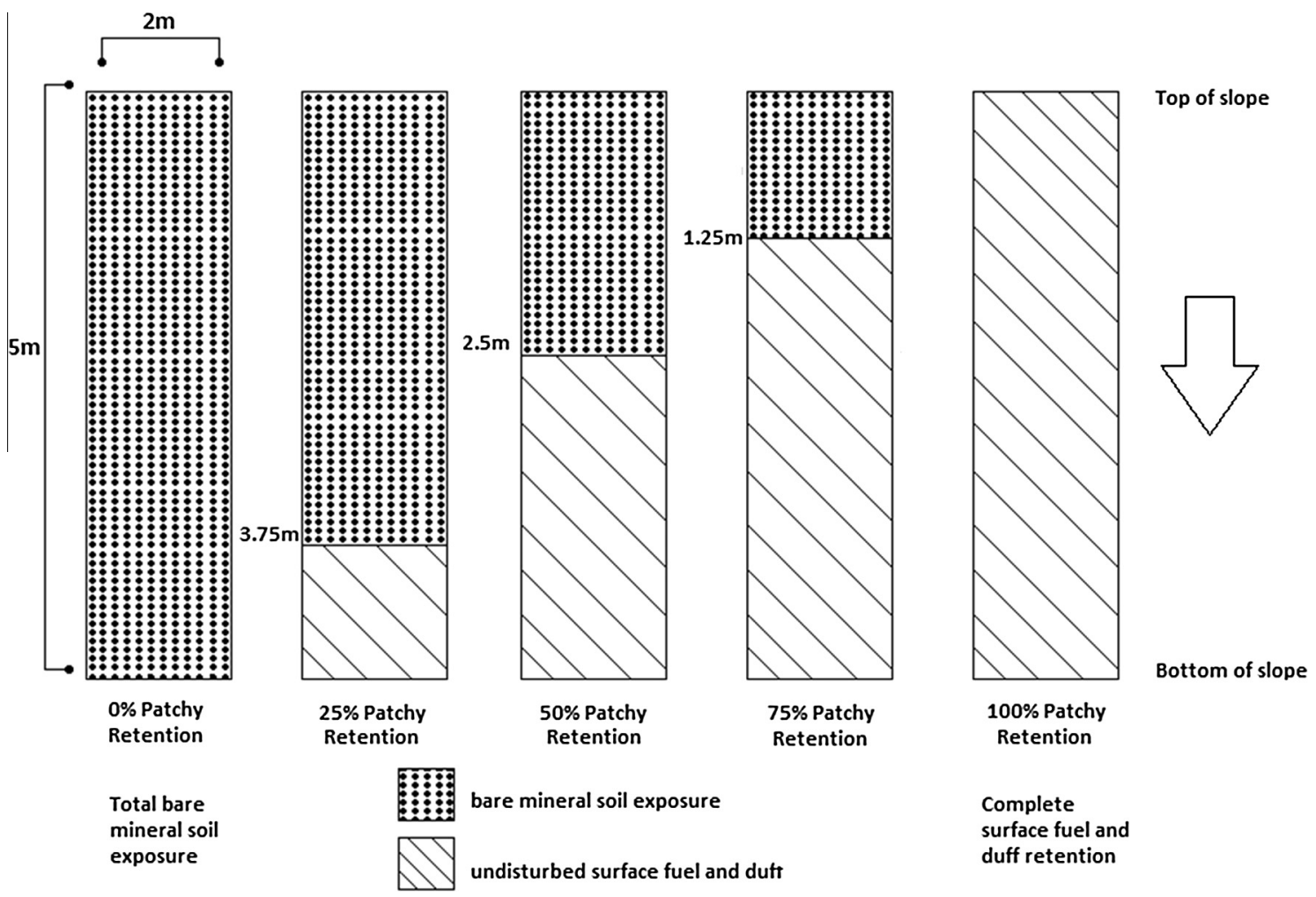

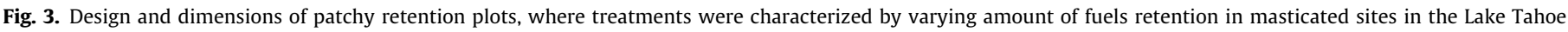
Basin, California and Nevada. 

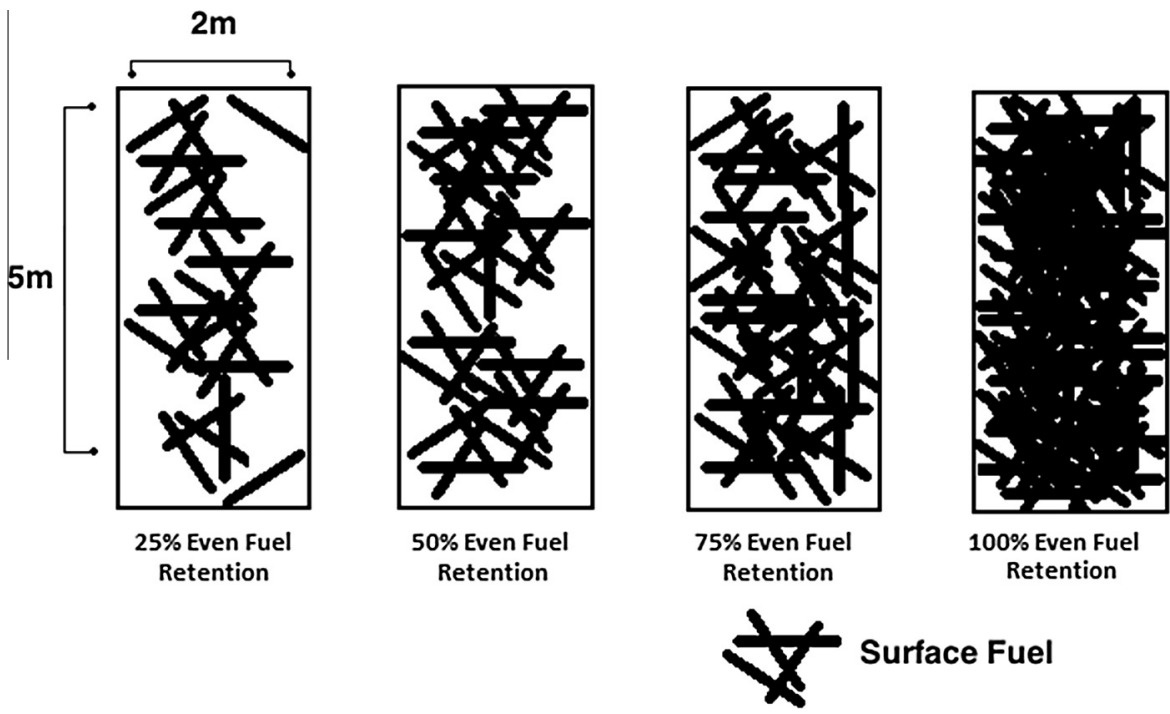

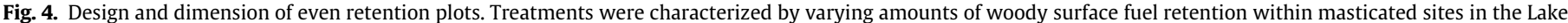
Tahoe Basin, California and Nevada. Percentages are a fraction of the mass of woody surface fuel measured on the control plot.

introduced by Levy and Madden (1933). Cover type and depth were classified at each sampling point $(n=90)$. Cover types assigned to each sampling point consisted of "ash" (consumption of all available fuels resulted in an ash deposit), "bare mineral soil" (consumption of all available fuels resulted in complete bare soil exposure), "incomplete burn" (incompletely burned or scorched fuels display some retention of structure and form), "incomplete/ash" (ash deposits combine with scorched needle cast), or "unburned" (fuels at the sampling point apparently untouched by fire). Averaging these data allows for estimates regarding the type, amount, and depth of organic matter in each plot. We developed a unique index of soil burn severity within each plot using the equation:

$B=\left(b+a+\left(0.5 * i_{a}\right)\right) / n * 100$

where $B$ is the estimated soil burn severity value (\%) within each plot, $b$ is the total number of sampling points labeled "bare mineral soil", $a$ is the total number of sampling points labeled "ash", $i_{a}$ is the total number of sampling points labeled "incomplete/ash", and $n$ is the total number of sampling points within each plot $(n=90)$. The total number of sampling points labeled "incomplete/ash" were divided in half due to the simultaneous presence of ash deposits and scorched needle cast within these areas. Fuel consumption around these sampling points was incomplete and lacked the severity to instigate erosion, and therefore assigned a limited contribution to overall plot burn severity percentages. Conversely, sampling points labeled "incomplete burn" were arbitrarily assigned no contribution to overall plot burn severity percentages since fuels in these areas retained some semblance of structure and may have mitigated erosion rather than exacerbated it. Soil burn severity classes followed those of Johansen et al. (2001) with low severity approximately corresponding to index values $<30 \%$, medium severity $30-60 \%$, and high severity $>60 \%$.

\subsection{Runoff simulation}

Runoff simulation was conducted in an identical manner at both masticated and prescribed fire sites. Water was transported to each site with large capacity water bladders, transferred into smaller capacity storage tanks, and pumped into a constant-level container (Fig. 5). The constant-level container introduced water directly to the runoff simulator, which applied water evenly across the top of the plot. At the lower end of the each plot, a sheet-metal collection apron was placed on the bare soil surface to funnel runoff into collection containers. A thin layer of wet bentonite clay was placed under the edge of the apron to prevent leakage beneath it.

Each plot received three $12-\mathrm{min}$ runs of concentrated flow at $15 \mathrm{~L} \mathrm{~min}^{-1}$. The purpose of the three runs was to account for variation in erosion and infiltration rates over time as fine material was flushed away and the soil saturated from initially dry conditions. Runoff was collected at $60 \mathrm{~s}$ intervals in tared containers until the cessation of flow for each run. The time for runoff to reach the collection apron was recorded. If water failed to reach the collection apron the run was labeled "No Collection/100\% infiltration". Subsamples of runoff were collected for laboratory analysis at three-minute intervals. Total runoff mass was recorded using a field scale. Typically, 10-15 min elapsed between each run.

\subsection{Runoff sample processing}

Analysis for masticated and prescribed fire sites included measurements of infiltration, total runoff, and total suspended sediment (TSS) content in subsample runoff collection. Infiltration was determined by calculating the difference between total applied water and total runoff collected. TSS was determined by standard gravimetric methods (Gray et al., 2000). Total sediment yield from each plot was estimated from runoff mass and subsample TSS data. Linear interpolation was used to determine TSS values for time intervals between subsample collections in order to provide a continuous record for the estimate of sediment yield.

Subsamples from prescribed fire sites were analyzed for particle-size distribution (e.g., Stubblefield et al., 2006) using a laser diffraction particle-size analyzer (LS-320, Beckman Coulter Inc., Miami, FL). To determine the proportion of different particle-size classes, percentile distributions generated by the particle-size analyzer were multiplied by the subsample TSS results to yield mass concentrations for the size classes $<1000 \mu \mathrm{m},<100 \mu \mathrm{m},<10 \mu \mathrm{m}$, and $<1 \mu \mathrm{m}$. Soil particle-size distributions derived from runoff samples in prescribed fire sites were characterized using the maximum size $\left(D_{i}\right)$, with $i$ corresponding to the percentage of particles less than that size.

\subsection{Data analysis}

For masticated sites, a three-factor analysis of variance (ANOVA) was performed (Zar, 1999) using a linear model to deter- 


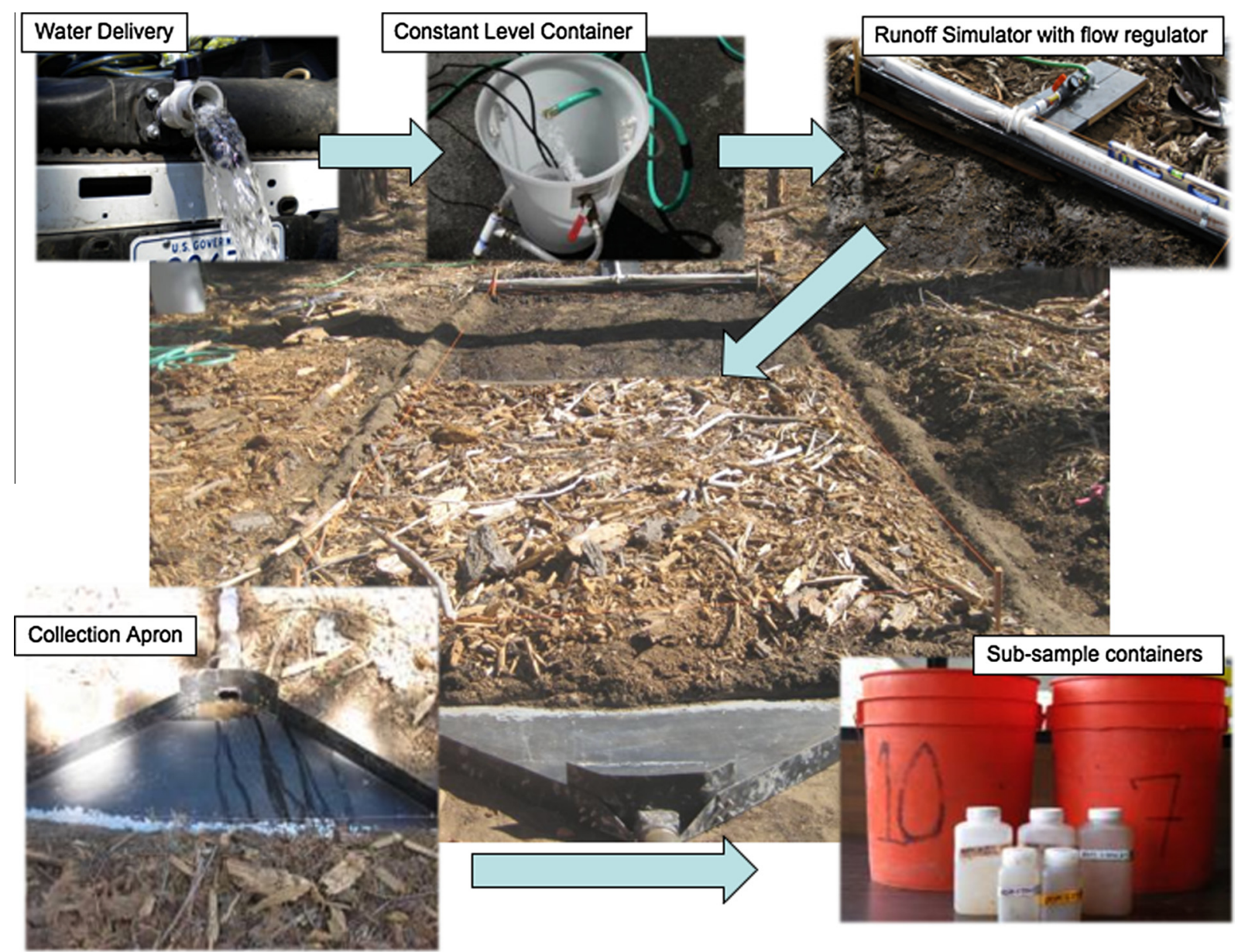

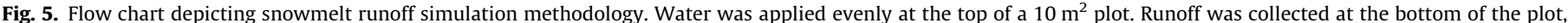
allowing for the measurement and observation of rill erosion processes at a scale applicable to hillslope erosion.

mine if site, slope, and treatment condition significantly influenced total sediment discharged for patchy and even treatments $(\alpha=0.05)$. Sequential sum of squares was used to remove the effects of site and slope and test for significant differences in sediment yield due to treatment. A post hoc Tukey test was performed as a pairwise comparison of mean treatment sediment yields to examine if significant differences occurred between masticated treatments.

For prescribed fire sites, a three-factor ANOVA was also performed using a linear model to determine if site, slope, and percentage of plot area burned significantly influenced total sediment discharged. Adjusted sum of squares tested the amount of variation explained by percentage of plot area burned when site and slope variables were treated as covariates.

For both masticated and prescribed fire sites, sediment yield and slope variables were log-transformed prior to analysis to improve normality of residuals. In order to transform sediment yield data, a value of 0.001 was added to all treatment sediment yields across masticated and prescribed fire sites so that treatments that garnered no sediment yield (i.e. contained zero values) could be transformed. All ANOVA statistical analyses were conducted using Minitab software ${ }^{\wedge}$ (Minitab Inc., Version 15.1, 2007). For prescribed fire sites, Tobit-piecewise regression (Mekbunditkul and Siripanich, 2010) was used to determine an erosion threshold because it accounts for unequal variances across the gradient of area burned. Tobit-piecewise regression was conducted using SAS (SAS Institute Inc., Version 9.4).

\section{Results}

\subsection{Soils and particle-size distributions}

Across all sites, soil textures varied between loamy sands and sandy loams. Higher field bulk density tended to be correlated with lower infiltration rates at masticated sites. Exceptions included the Chamonix site, where infiltration rates $\left(0.05 \mathrm{~mL} \mathrm{~s}^{-1}\right)$ and soil bulk density $\left(0.81 \mathrm{~g} \mathrm{~cm}^{-3}\right)$ were low, and the Skyland site, where infiltration rates $\left(0.40 \mathrm{~mL} \mathrm{~s}^{-1}\right)$ and soil bulk density $\left(1.38 \mathrm{~g} \mathrm{~cm}^{-3}\right)$ were high (Table 1 ). Hydraulic conductivity $(K)$ values were the lowest at the Chamonix $\left(0.0003 \mathrm{~cm} \mathrm{~s}^{-1}\right)$ and Angora $\left(0.0004 \mathrm{~cm} \mathrm{~s}^{-1}\right)$ sites (Table 1). Volumetric water content $(\theta)$ at the time of the runoff simulations was low at all sites, varying from only $4 \%$ to $11 \%$.

Sediment yield had the strongest positive relationship with the finest particle-size classes $\left(D_{10}\right)$ within each sample and the strongest negative relationship with the coarsest $\left(D_{90}\right)$ size classes within each sample (Fig. 6). Overall median particle-sizes $\left(D_{50}\right)$ were highest in the decomposed granitic soil types of Slaughterhouse 1 and Slaughterhouse 2 sites, ranging from $57 \mu \mathrm{m}$ to $418 \mu \mathrm{m}$ and $156 \mu \mathrm{m}$ to $475 \mu \mathrm{m}$, respectively. Overall, median particle-sizes were lowest in the volcanic soil types of the Dollar 2 site, ranging from $28 \mu \mathrm{m}$ to $90 \mu \mathrm{m}$.

Average surface soil hydraulic conductivity $\left(0.0056 \mathrm{~cm} \mathrm{~s}^{-1}\right)$ and $10 \mathrm{~cm}$ depth $K$-values $\left(0.0086 \mathrm{~cm} \mathrm{~s}^{-1}\right)$ were greatest in the decomposed granitic soils in the Slaughterhouse 2 site. Average $K$-values were smallest at the surface in the volcanic soils of the Incline 2 


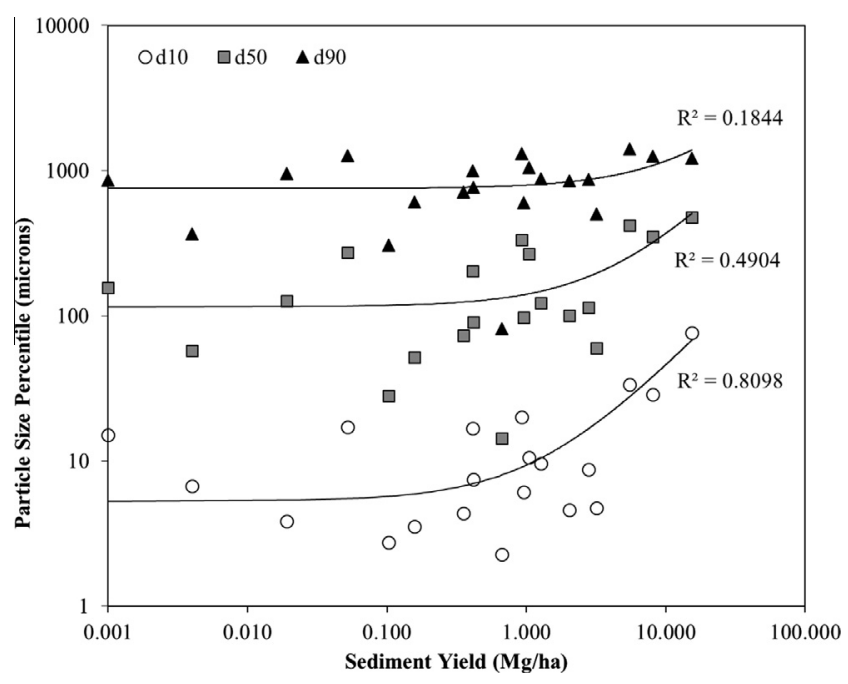

Fig. 6. Sediment particle-size percentile $(\mu \mathrm{m})$ vs. Sediment yield $(\mathrm{kg})$ measured in $D_{10}, D_{50}$, and $D_{90}$ particle-size distribution percentiles of samples collected in runoff from prescribed fire sites in the Lake Tahoe Basin, California and Nevada. A value of 0.001 was added to each measurement of sediment yield in order to conduct log transformations. Each of the three measures of sediment particle-size distribution is fit with a power relationship between sediment particle size percentile and sediment yield.

site $\left(0.0006 \mathrm{~cm} \mathrm{~s}^{-1}\right)$ and at a $10 \mathrm{~cm}$ depth in the volcanic soils of Dollar $2\left(0.0006 \mathrm{~cm} \mathrm{~s}^{-1}\right)$ and Burton 2 sites $\left(0.0006 \mathrm{~cm} \mathrm{~s}^{-1}\right)$. Average measurements of dry soil bulk density were greatest at the Dollar $2\left(0.89 \mathrm{~g} \mathrm{~cm}^{-3}\right)$ site and smallest at the Burton 1 site $\left(0.77 \mathrm{~g} \mathrm{~cm}^{-3}\right)$. At Incline 1 , Incline 2, Burton 1, and Burton 2 sites, large discrepancies were found between volumetric water content $(\theta)$ values obtained by the soil moisture probe and $\theta$-values obtained by bulk density methodology. Moisture probe and bulk density derived $\theta$-values were relatively consistent in both Slaughterhouse sites.

\subsection{Runoff in masticated and prescribed fire sites}

As expected, mean fuel depth to bare mineral soil was lower in even retention mastication treatments $(6 \mathrm{~cm})$ than within patches in the patchy retention mastication treatments $(15 \mathrm{~cm})$ because litter and duff were removed in the former. Fuel depth among even retention treatments was greatest at the Chamonix site $(10 \mathrm{~cm} \pm 2 \mathrm{~cm}$, where \pm indicates standard deviation) and the lowest at the Granlibakken site $(4 \mathrm{~cm} \pm 2 \mathrm{~cm})$. Across all sites, mean fuel depth increased linearly with increased amounts of surface fuel retention among even retention treatments. Mean depth to bare mineral soil among patchy retention treatments was greatest at the Inspiration Point site $(22 \mathrm{~cm} \pm 4 \mathrm{~cm})$ and lowest at the Angora site $(10 \mathrm{~cm} \pm 4 \mathrm{~cm})$. Across all sites, mean depth to bare mineral soil was highest in patchy retention treatments with $50 \%$ soil exposure $(17 \mathrm{~cm} \pm 1 \mathrm{~cm})$ and lowest in treatments with $25 \%$ retention $(14 \mathrm{~cm} \pm 1 \mathrm{~cm})$. Depths were averaged from measurements made from remaining patches, not bare areas.

In masticated sites, runoff sediment yields were greatest in treatments characterized by complete soil exposure and lowest in treatments characterized by complete surface fuel retention (Fig. 7). Within even retention treatments (Fig. 7a), average sediment yields were highest in plots where $25 \%$ of surface fuels were retained $\left(0.50 \mathrm{Mg} \mathrm{ha}^{-1}\right)$ and lowest in plots where $100 \%$ of surface fuels were retained $\left(0.03 \mathrm{Mg} \mathrm{ha}^{-1}\right)$. With subtle increases in surface fuel retention within plots, average sediment yield decreased substantially ( $83 \%$ reduction from $25 \%$ to $50 \%$ fuel retention). The average amount of erosion in $25 \%$ even retention treatments was

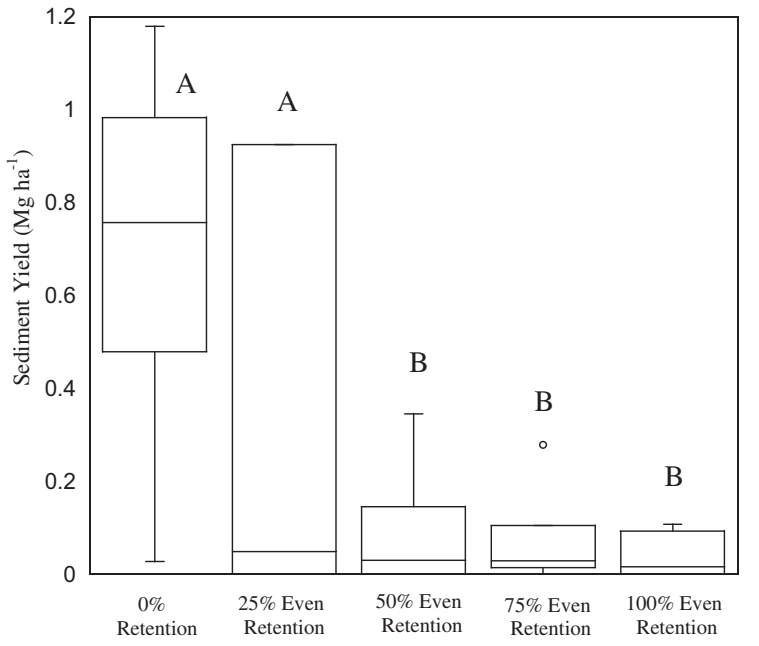

(a) Sediment Yield for Even Retention Treatments

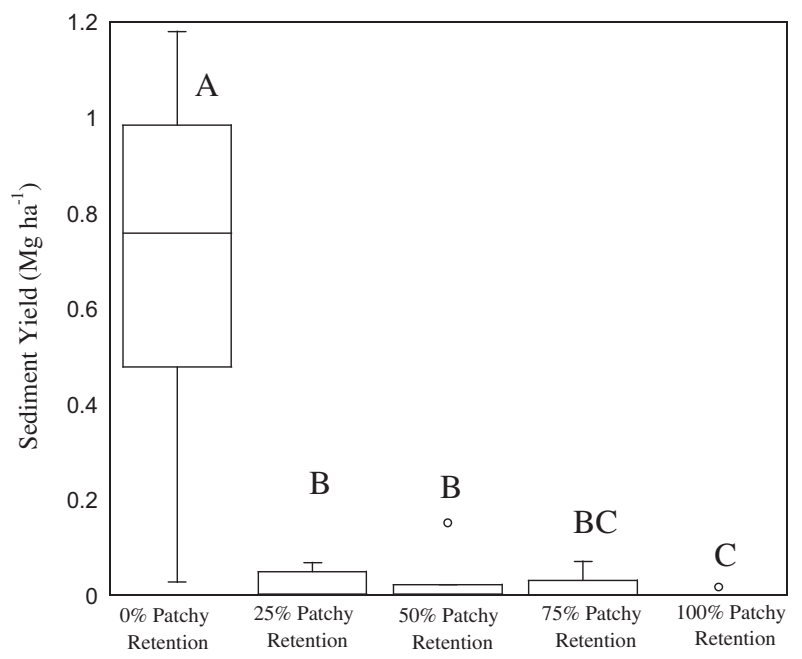

(b) Sediment Yield for Patchy Retention Treatments

Fig. 7. Sediment yields for fuel redistribution treatments, Lake Tahoe CA-NV. (a) Even Retention and (b) Patchy Retention. 100P denotes $100 \%$ fuel retention on erosion plot. $75 \mathrm{P}$ denotes $75 \%$ fuel retention, and so forth for $50 \mathrm{P}, 25 \mathrm{P}$ and $0 \mathrm{P}$. $100 \mathrm{~W}$ denotes $100 \%$ of control plot masticated fuel weight retained evenly over erosion plot. $75 \mathrm{~W}$ denotes $75 \%$ of control plot fuel mass evenly distributed over erosion plot, and so forth for $50 \mathrm{~W}$ and $25 \mathrm{~W}$. Treatments with different letters have significantly different means at $P \leqslant 0.05$ (Tukey-Kramer HSD).

$44 \%$ less than in plots with $0 \%$ fuel retention. Average sediment yield in 50\% (0.09 $\left.\mathrm{Mg} \mathrm{ha}^{-1}\right)$ and 75\% (0.06 $\left.\mathrm{Mg} \mathrm{ha}^{-1}\right)$ even retention treatments was not significantly different $(P<0.001)$. In patchy fuel retention treatments (Fig. $7 \mathrm{~b}$ ), average sediment yield was similar in plots characterized by $50 \%$ and $25 \%$ fuel retention, but both were approximately $97 \%$ lower relative to average sediment yields garnered from plots characterized by $0 \%$ fuel retention. Sediment yield for $75 \%$ and $100 \%$ patchy retention did not differ from $50 \%$ retention.

Even fuels retention and patchy retention treatments were significant predictors of sediment yields $(P<0.001)$. There were significant differences in sediment yields among the eight masticated sites $(P=0.011)$. Slope (range $=12-33 \%)$ was not a significant predictor in total sediment yield $(P=0.791)$. Mean sediment yields in mastication treatments characterized by $0 \%$ fuel retention and $25 \%$ even retention were significantly higher than sediment yields measured in the other treatments (Fig. 7, Tukey test, 95\% confidence level). Patchy retention sites had significantly 


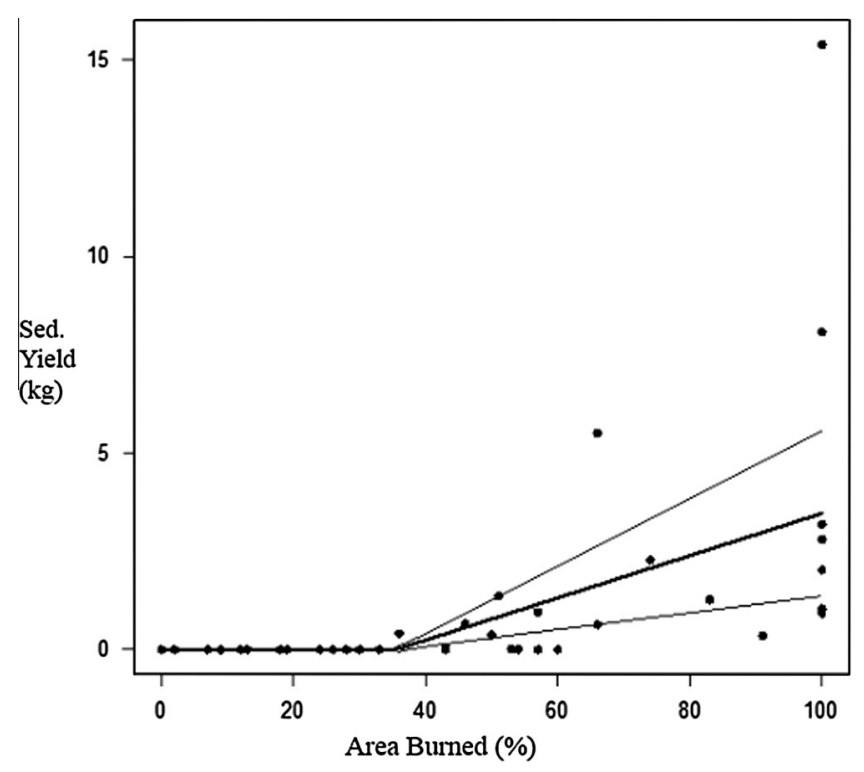

Fig. 8. The effects of percentage of plot area burned on sediment yield $(\mathrm{kg})$ with prescribed fire sites of the Lake Tahoe Basin, California and Nevada. Data are fit with piecewise Tobit regression (dark line) with a threshold at $35 \%$ of plot area burned. Light lines indicate 95\% confidence intervals.

lower sediment yields than even retention sites (Tukey test, 95\% confidence level).

Sediment yields and runoff from masticated sites were closely aligned with parent material. Volcanic soils (Ward, Chamonix, and Granlibakken) averaged higher sediment yields than sites with granitic soils (Skyland, Roundhill, Angora, Bliss, and Inspiration Point) in three out of four even retention treatments and in four out of five patchy retention treatments. Slopes in sites with volcanic soil types were steeper than those in corresponding sites with granitic soil types by approximately $5 \%$, but since slope was not a significant predictor of erosion in our analysis, the discrepancy does little to explain the association between sediment delivery and soil type.

In prescribed fire sites, percentages of area burned varied among plots within sites, ranging from $0 \%$ to $100 \%$. Tobit piecewise regression indicated a positive relationship between percentages of plot area burned and total sediment yield, with a threshold of sediment yield at ca. $>35 \%$ of plot area burned (std. error 0.722 , Fig. 8). The highest sediment yield occurred in plots with percentage area burned between $66 \%$ and $100 \%$. Plot area burn percentage was a highly significant predictor of total sediment yield (ANOVA; $P<0.001)$. As in the masticated fuels treatments, plot slope (range $=20 \%$ to $48 \%$ ) was not a significant predictor of sediment yield $(P=0.693)$, nor was "site" $(P=0.086)$.

Of the eight prescribed fire sites, only two (Slaughterhouse 1 and Slaughterhouse 2) had granitic soil origins, making a direct comparative analysis of results between granitic vs. volcanic soil types difficult. Average sediment yields were higher in decomposed granitic sites than in volcanic soil types.

\section{Discussion}

Large differences in sediment yield were observed across fuels treatments that exposed the most bare soil and those that retained fuels on the soil surface. Masticated treatments characterized by either relatively low loads of uniformly distributed woody surface fuel, or only small patches of masticated material, along with underlying duff were sufficient to mitigate severe erosion by trapping sediment and increasing infiltration. In prescribed fire plots, heterogeneous patches of unburned or less severely burned islands of surface fuel were sufficient to mitigate erosion in a similar manner. Reduction in erosion was especially pronounced if fire burned less than $35 \%$ of the plot area. Thus, in the most macroscopic sense, two very different surface fuel treatments observed in this study shared a common outcome: as areas of exposed mineral soil increased, the amount of erosion due to simulated snowmelt runoff increased by orders of magnitude. By exploring the details of this overall finding, land managers in the Lake Tahoe Basin and elsewhere can pursue strategies that balance erosion control with wildland fuel reduction objectives.

\subsection{Masticated fuels and erosion}

Our results strongly indicate that increased surface cover reduces erosion rates.

Within the masticated sites of this study, surface cover consisted primarily of masticated woody fuel, which, along with underlying layers of duff, reduced surface runoff velocity and held soils in place during simulated snowmelt runoff. As the amount of plot area covered in fuel and duff increased within each treatment, rill development decreased, infiltration increased, and sediment delivery was impeded. In most cases across sites, dramatic reductions in erosion rates from bare soil conditions ( $0 \%$ fuel retention) were observed for the minimum tested surface cover category. For example, retention of only a $25 \%$ patch of masticated fuel and duff reduced average sediment delivery by $97 \%$. Even distribution of $25 \%$ of original masticated woody fuel loading resulted in a $44 \%$ reduction in sediment delivery.

Our results support research findings from Lake Tahoe (Naslas et al., 1994; Hatchett et al., 2006; Grismer et al., 2008) and more broadly (Benavides-Solorio and MacDonald, 2001; Johansen et al., 2001; Molinar et al., 2001; Pannkuk and Robichaud, 2003; Robichaud et al., 2013). Hatchett et al. (2006) found that residual surface fuels following mechanical mastication reduced erosion by promoting high rates of infiltration and limiting soil detachment from erosive forces due to overland flow.

Patchy retention of masticated fuels was more effective at mitigating erosion than even retention. Even retention treatments averaged $0.16 \mathrm{Mg} \mathrm{ha}^{-1}$ while patchy retention averaged $0.01 \mathrm{Mg} \mathrm{ha}^{-1}$. The greater efficiency of patchy fuels at reducing erosion is likely at least in part due to the fact that the underlying duff was retained in the patchy treatment, whereas the even woody fuels distribution treatments depended on the woody material alone to trap sediment and increase infiltration. The magnitude of the erosion reduction with patchy fuels was also likely enhanced because the retained patch was always placed at the bottom of the erosion simulation plot. Had the retained patch been randomly placed, the improvement would have been somewhat less.

Overall results derived from mastication treatments point to several conclusions regarding small-scale surface erosion. The complete exposure of a hillslope to bare soil offers the greatest potential for severe erosion as a result of rill erosion. Effectiveness in mitigating erosion increases as the application of evenly distributed masticated surface fuel to a bare soil (without litter and/ or duff) increases. This finding is supported by other studies in the literature (Bautista et al., 1996; Wagenbrenner et al., 2006). This treatment approximated management objectives at one of our sites (Angora), where small non-merchantable timber was masticated following a high severity wildfire in order to mitigate erosion concerns. At many non-wildfire sites, masticated wood would likely be distributed on top of existing duff, which would likely make it even more effective. This surface cover combination increases the potential for infiltration, increases soil water holding capacity, prevents rill formation, and traps suspended sediment. Our results demonstrate that even small patches of surface fuel, 
or surface fuel and duff layers can be effective in preventing severe erosion due to snowmelt runoff. Further research is needed to refine the levels of retained fuels appropriate for different forest floor conditions, and develop mastication and prescribed fire treatments that achieve target fuel levels.

Mastication is not appropriate for all areas. Steep slopes and access to remote areas may limit use of equipment. Equipment used for mechanical mastication is expensive to operate and produces greenhouse gases. However, strategic placement of treated areas may reduce fire spread without the need to treat the entire landscape. Our findings are also relevant to any fuels treatment that affects the amount and spatial distribution of surface fuels, not just mastication.

When burned, excessive post-treatment masticated fuel loads can lead to substantial mortality of residual trees due to crown scorch (Knapp et al., 2011). A potential also exists for biological damage from soil heating during fire in masticated fuelbeds, particularly in dry soils with masticated fuel depths exceeding $7.5 \mathrm{~cm}$ (Busse et al., 2005). Our experiment suggests that application of masticated fuels commonly exceeds that threshold in the Lake Tahoe Basin, as the average depths for our eight control plots was $8.4 \mathrm{~cm}$. Erosion was effectively mitigated when only $50 \%$ of available masticated fuels were evenly retained on plot surfaces. Thus, the threat of erosion can be mitigated with lesser amounts of woody fuels, thereby reducing fire hazard and potential soil heating concerns. Our work adds to a growing body of research (Johansen et al., 2001; Robichaud et al., 2013) indicating that the competing objectives of erosion mitigation and fire hazard could be effectively met with far less ground covered by masticated wood.

The patchy retention treatments potentially limit fire hazard through different processes than minimizing fuel depths. While patchy retention of fuel reduced the amount of fuel in each plot (a key driver of soil heating; DeBano et al., 1998; Busse et al., 2005), it also created discontinuities in the fuelbed, which can alter fire behavior by slowing or stopping fire spread. Discontinuity of fuels can result in less of the ground surface experiencing fire and reduce the total amount of fuel consumed (Knapp et al., 2005). This unburned forest floor and groundcover is then available to trap sediment and mitigate erosion.

In this study we found that retaining even small patches of surface fuel and duff (25\% of plot area) substantially mitigated erosion. Thus the area of soil potentially subjected to excessive heat would be highly concentrated within a limited area of fuel, litter, and duff. While there was added benefit of covering 50\% and $75 \%$ of the ground in fuels, these higher fuel amounts also increase fuel continuity and thus the potential for fire spread and soil heating. A $25 \%$ patchy retention mastication treatment appears to provide sufficient surface protection to mitigate erosion but not enough to exacerbate the effects of wildland fire. Further work using a finer range of gradations (e.g. $20 \%, 30 \%, 40 \%$ ) would provide more specific guidance. The patchy retention results may not be applicable to regions with lower litter and duff accumulations than the Lake Tahoe Basin. Guidance for specific amounts of soil coverage needed also depends on slope and soil type, which varies greatly in forested areas where both erosion and fire hazard are concerns. For example, erosion studies of burned areas in Idaho, Colorado and Washington found that wood mulch cover, applied at 4.5-12 $\mathrm{Mg} \mathrm{ha}^{-1}$ over $51-57 \%$ of treatment plots, was effective in reducing sediment yield as compared to untreated controls, but the study did not evaluate lower coverage percentages (Robichaud et al., 2013).

\subsection{Prescribed fire and erosion}

Retention of groundcover resulting from burn patchiness lowered erosion rates as compared to more fully burned areas. Within our study the greatest erosion potential was found when the burned area within each plot exceeded ca. 50\% (Fig. 8). By exploring this threshold along with other intrinsic variables that constitute burn severity, a wide range of factors that contributed to erosion in prescribed fire sites can be better understood.

In Tahoe Basin sites where prescribed burn severity was predominantly low (Incline 1, Incline 2, and Burton 2), fires consumed only a portion of the surface fuel and measured erosion was generally minimal. In sites where burn severity was moderate (Slaughterhouse 1, Slaughterhouse 2, and Dollar 2), surface fires partially consumed surface litter and charred but did not entirely consume the duff. Large patches of bare soil were generally absent and areas with substantial ground cover were sufficient to impede or halt rill formation.

In sites where burn severity was high (Burton 1 and Dollar 1), nearly the entire forest floor was consumed and mineral soil structures were significantly altered. Large patches $\left(\sim 10 \mathrm{~m}^{2}\right)$ of exposed soil were generated and linked together through areas of thin, disturbed groundcover. Flows passing over bare mineral soil formed rills that transported large amounts of sediment downslope (Fig. 8). Previous researchers have recorded increases in post-fire sediment yields when bare mineral soil increased above $30-40 \%$ (Robichaud, 1996; Pannkuk and Robichaud, 2003; BenavidesSolario and McDonald, 2005). Meta-analysis of rainfall simulator experiments found a similar threshold increase in erosion yield when soil burn severity increased from low ( $<30 \%$ bare mineral soil cover) to moderate (30-60\% bare mineral soil cover) for forest shrub and grassland (Veira et al., 2015). An additional issue with the potential to influence erosion is the formation of waterrepellent conditions within the soil with high severity wildfire (DeBano et al. (1998). However, the impact of the complete consumption of litter and duff on erosion rates has been found to be more detrimental than the effects of increased water repellence (Sevink et al., 1989; Scott and van Wyk, 1990; Marcos et al., 2000; Certini, 2005).

Along with bare soil exposure, soil texture (i.e. particle size distribution) and structure help explain variation in sediment yield in prescribed fire sites. Soils with coarse texture and strong structure resist detachment forces of rill erosion and infiltrate water more rapidly, thus reducing rill-forming processes. Particle-size distribution is not directly affected by fire (Oswald et al., 1999) but soil surface particles became disaggregated in plots that experienced high burn severity and are thus more susceptible to erosion (Wells et al., 1979; Robichaud and Waldrop, 1994; DeBano et al., 1998; Elliot et al., 2010).

Sites on granitic soils (Slaughterhouse 1 and 2) generally had larger particle sizes than other sites. Across all prescribed fire sites, particle size was typically largest in plots where soil burn severity was the highest. This confounding result meant that the relative influence of burn severity and particle size on erosion cannot be disentangled in these experiments, and is worth further investigation.

In addition to affecting erodibility and transport, particle size mediates the impact of sediment on aquatic systems. Visual clarity is a highly valued measure of Lake Tahoe's aesthetics (Goldman, 2000). Smaller particles $(\sim 1 \mu \mathrm{m})$ have a greater impact on diminished water clarity by scattering light much more effectively than larger $(\sim 10 \mu \mathrm{m})$ particles (Boss et al., 2001; Swift et al., 2005). In addition, smaller particles persist in the water column rather than settling with gravity. In this study, particle sizes of eroded sediment were relatively large, however there was a significant fraction below $10 \mu \mathrm{m}$ (Fig. 6) that would be expected to reduce clarity if transported to the lake. This underscores the importance of meeting erosion control objectives in fuels treatments.

Plot slope was not found to be a significant predictor of sediment yield $(P=0.086)$. This result is likely due to relatively subtle 
variation in slope among treated sites available for this study. Steeper slopes exist, but are unlikely to be treated with mastication and less likely to be treated with prescribed fire. Operation of mastication equipment is typically limited to slopes $<45 \%$ (Vitorelo et al., 2011) and steep slopes can make prescribed fire more challenging to implement. For these reasons, and because it is well established that rill and sheetwash erosion increase with slope (Fox and Bryan, 2010) our results should not be extrapolated to steeper sites.

A clear comparison between volcanic soils and granitic soils was not possible for prescribed fire sites because of lack of replicates (only two granitic sites). However an erosion threshold was still observed for granitic soils at the Slaughterhouse sites. Both sites had high infiltration rates that led to low erosion rates until a threshold of plot area burned was exceeded. At Slaughterhouse 1 , sediment yields were minimal in plots where $13 \%$ and $54 \%$ of the area had been burned to mineral soil, moderate in a $36 \%$ burned plot, and high in the $66 \%$ and $100 \%$ burned plots. At the Slaughterhouse 2 site, no sediment yield was observed for plots with up to $60 \%$ of the surface area burned, despite steep slopes. The 100\%-burned plot, had the highest erosion rates in this study. Grismer and Hogan (2005) noted that larger average particle-sizes in granitic soils led to greater infiltration capacities, but provide high degrees of sediment availability for erosion. Croke et al (2001) also found that granite soil types can be highly erodible.

Scale is known to have a strong effect on experimental results. Moving from a plot to hillslope scale, erosion rates can initially increase as there become sufficient overland flow to trigger the development of rills. However as scale increases, sediment sinks, slope decreases, and areas of high infiltration become more likely, acting to decrease sediment delivery (Boix-Fayos et al., 2006; deVente and Poesen, 2005; Wagenbrenner and Robichaud, 2014). By focusing on rill erosion simulation (water entering at the top of the plot), rather than rainfall simulation (i.e. sprinklers) we were able to examine a process typically operating at larger scales. Our $2 \mathrm{~m} \times 5 \mathrm{~m}$ plot size is in accordance with results reported by Robichaud et al. (2010) in which $4 \mathrm{~m}$ plot length was found to be sufficient for rill simulation in a comparison of results from $2 \mathrm{~m}$, $4 \mathrm{~m}$, and $6 \mathrm{~m}$ lengths in forested areas similar to our study site. We felt this size was sufficiently large to create rills and facilitate the observation of patchiness effects on erosional processes. A larger plot size would have been logistically difficult as all water was transported to the sites. Numerous observations made during the experiment indicated rill formation was in fact occurring. It is important to acknowledge that experiments conducted over longer time periods, at hillslope scales, or using rainfall rather than rill simulation would produce different sediment loading rates. However, plot-scale measurements provide a powerful way to analyze local fluxes of water and sediment under controlled inputs (Wainwright et al., 2000; Mathys et al., 2005).

\subsection{Conclusions}

The results of this experiment have immediate implications for managers seeking to implement surface fuel reduction treatments in areas where erosion is also a concern. The Lake Tahoe Basin shares its fire management constraints with other locations with extensive wildland-urban interface and issues involving air quality (Quinn-Davidson and Varner, 2012). Where prescribed fire is not an option, mechanical treatments that produce only low fuel loads or are designed to distribute fuels in a patchy manner would do less to increase fire hazard. To reduce wildfire spread, masticated fuels can be constrained to patches or strips with the remainder of the area with little or no fuel. Avoiding deep masticated fuels can minimize the potential for damaging heat (cf. Busse et al., $2005<7.5 \mathrm{~cm}$ ) in the event of a wildfire. Our results suggest that masticated fuel applications that are $50-75 \%$ of depths found at field sites measured in this study are still effective in controlling erosion. Further research is needed to generate more specific guidelines for percent bare soil in masticated fuel applications. However, this study provides an important proof of concept, that ground cover by masticated fuels need not cover $100 \%$ of the project area to achieve erosion mitigation.

Where prescribed fire is an option for reducing fuel loads, managers can develop burning prescriptions that lead to patchy burns. Our results indicate that prescribed fires retaining $>50 \%$ litter and duff produce sufficient unburned islands to capture sediments while simultaneously consuming sufficient fuel to reduce the probability of high fire severity. The ground cover percentage that we found for prescribed burns was higher than that for masticated fuels. We believe this is because areas where prescribed burns were being conducted had lower litter and duff thicknesses, possibly as a result of previous burns. This resulted in thinner organic matter accumulations, less able to absorb runoff and control erosion. Future research should explore the role of duff and litter accumulation thickness on runoff more explicitly.

If patches of the landscape burned to the mineral soil surface erode during a snowmelt runoff event, adjacent islands of unburned litter retain the capacity to trap sediment and generate infiltration. Fuel consumption by fires varies tremendously, dependent on fuel moisture and fire weather. Burning when fuels are moist limits fire intensity and increases heterogeneity of burn severity (Fig.1; Martin and Sapsis, 1992; Knapp and Keeley, 2006). In the dry forests of the Sierra Nevada, burning prescriptions can take advantage of the extended snowpack followed by a somewhat predictable dry season to create ideal conditions. Alternatively, early fall rain and snow with intervening dry periods might provide optimal conditions for creating a patchy burn (Banwell et al., 2013).

These results offer promise for Lake Tahoe and other fire-prone landscapes where fire hazard and erosion mitigation are seen as conflicting objectives. We hope this work adds to the information managers can draw on to take active steps towards creating a resilient forest.

\section{Acknowledgements}

Funding for this research was provided by the Bureau of Land Management through the sale of public lands as authorized by the Southern Nevada Public Land Management Act (SNLPMA). This Round 8 SNLPMA research grant was supported by an agreement with the USDA Forest Service Pacific Southwest Research Station. We appreciate the help of A. Geritz, N. Schroeter, E. Banwell, A. Heck, R. Arst-McCullough, M.E. Grismer and M. Hogan. We thank J. Baldwin for statistical assistance and J.L. Beyers for her review of the manuscript.

\section{References}

Agee, J.K., Skinner, C.N., 2005. Basic principles of forest fuel reduction treatments. For. Ecol. Manage. 211, 83-96.

Allen, C.D., Savage, M., Falk, D.A., Suckling, K.F., Swetnam, T.W., Schulke, T., Stacey, P. B., Morgan, P., Hoffman, M., Klingel, J.T., 2002. Ecological restoration of southwestern ponderosa pine ecosystems: a broad perspective. Ecol. Appl. 12, 1418-1422.

Banwell, E.M., Varner, J.M., Knapp, E.E., Van Kirk, R.W., 2013. Spatial, seasonal, and diel forest floor moisture dynamics in Jeffrey pine-white fir forests of the Lake Tahoe Basin, USA. For. Ecol. Manage. 305, 11-20.

Bautista, S., Bellot, J., Vallejo, V.R., 1996. Mulching treatment for post-fire soil conservation in a semiarid ecosystem. Arid Soils Res. Rehabil. 10, 235-242.

Benavides-Solario, J.D., McDonald, L.H., 2005. Measurement and prediction of postfire erosion at the hillslope scale, Colorado Front Range. Int. J. Wildland Fire 14, 457-474.

Benavides-Solorio, J.D., MacDonald, L.H., 2001. Post-fire runoff and erosion from simulated rainfall on small plots, Colorado Front Range. Hydrol. Process. 15, 2931-2952. 
Boix-Fayos, C., Martínez-Mena, M., Arnau-Rosalén, E., Calvo-Cases, A., Castillo, V., Albaladejo, J., 2006. Measuring soil erosion by field plots: understanding the sources of variation. Earth Sci. Rev. 78, 267-285.

Boss, E., Twardowski, M.S., Herring, S., 2001. Shape of the particulate beam attenuation spectrum and its inversion to obtain the shape of the particulate size distribution. Appl. Opt. 40, 4885-4893.

Busse, M.D., Hubbert, K.R., Fiddler, G.O., Shestak, C.J., Powers, R.F., 2005. Lethal soil temperatures during burning of masticated forest residues. Int. J. Wildland Fire $14,267-276$.

California Department of Forestry and Fire Protection, 2011. Angora Fire Incident Information [Internet]. Cal Fire Archived Incident Report, El Dorado County (Ca), c2011. <http://cdfdata.fire.ca.gov/incidents/incidents_details_info?incident_id= 184> (cited 30.06.10).

Certini, G., 2005. Effects of fire on properties of forest soils: a review. Oecologia 143, $1-10$.

Coats, R.N., Leonard, R.L., Goldman, C.R., 1976. Nitrogen uptake and release in a forested watershed, Lake Tahoe Basin, California. Ecology 57 (5), 995-1004.

Croke, J., Hairsine, P., Fogarty, P., 2001. Soil recovery from track construction and harvesting changes in surface infiltration, erosion and delivery rates with time. For. Ecol. Manage. 143, 3-12.

DeBano, L.F., Neary, D.G., Folliott, P.F., 1998. Fire's Effects on Ecosystems. John Wiley and Sons, New York, New York.

deVente, J., Poesen, J., 2005. Predicting soil erosion and sediment yield at the basin scale: scale issues and semi-quantitative models. Earth Sci. Rev. 71, 95-125.

Donovan, G.H., Brown, T.C., 2007. Be careful what you wish for: the legacy of Smokey Bear. Front. Ecol. Environ. 5, 73-79.

Elliot, W.J., Miller, I.S., Audin, L., 2010. Cumulative Watershed Effects of Fuel Management in the Western United States. General Technical Report RMRSGTR-231, USDA Forest Service, Rocky Mountain Research Station, Fort Collins, Colorado.

Fox, D.M., Bryan, R.B., 2010. The relationship of soil loss by interrill erosion to slope gradient. Catena 38 (3), 211-222.

Gardner, J.V., Mayer, L.A., Clarke, J.E.H., 2000. Morphology and processes in Lake Tahoe (California-Nevada). Geol. Soc. Am. Bull. 112, 736-746.

Goldman, C.R., 1988. Primary productivity, nutrients, and transparency during the early onset of eutrophication in ultra-oligotrophic Lake Tahoe, CaliforniaNevada. Limnol. Oceanogr. 33, 1321-1333.

Goldman, C.R., 2000. Four decades of change in two subalpine lakes. Limnol. Oceanogr. 27, 7-26.

Goldman, C.R., Jassby, A.D., Powell, T., 1989. Interannual fluctuations in primary productivity: meteorological forcing in two subalpine lakes. Limnol. Oceanogr. 34, 310-323.

Gray, J.R., Glysson, G.D., Turcios, L.M., Schwarz, G.E., 2000. Comparability of Suspended-Sediment Concentration and Total Suspended Solids Data. U.S. Geological Survey Water-Resources Investigations Report 00-4191. Reston, Virginia.

Grismer, M.E., Ellis, A.L., 2006. Sediment particle-size distributions in runoff from disturbed soils in the Lake Tahoe Basin. Calif. Agric. 60, 72-76.

Grismer, M.E., Hogan, M.P., 2005. Evaluation of revegetation/mulch erosion control using simulated rainfall in the Lake Tahoe Basin: 1. Method assessment. Land Degrad. Dev. 15, 573-588.

Grismer, M.E., Ellis, A.L., Fristensky, A., 2008. Runoff sediment particle-sizes associated with soil erosion in the Lake Tahoe Basin, USA. Land Degrad. Dev. 19, 331-350.

Hatchett, B., Hogan, M.P., Grismer, M.E., 2006. Mechanical mastication thins Lake Tahoe forests with few adverse impacts. Calif. Agric. 60, 77-82.

Hessburg, P.F., Agee, J.K., Franklin, J.F., 2005. Dry forests and wildland fires of the inland Northwest USA: contrasting the landscape ecology of the presettlement and modern eras. For. Ecol. Manage. 211, 117-139.

Hunter, M.E., Omi, P.N., Martinson, E.J., Chong, G.W., 2006. Establishment of nonnative plant species after wildfires: effects of fuel treatments, abiotic and biotic factors, and post-fire grass seeding treatments. Int. J. Wildland Fire 15, 271-281.

Jassby, A.D., Reuter, J.E., Axler, R.P., Goldman, C.R., Hackley, S.H., 1994. Atmospheric deposition of nitrogen and phosphorus in the annual nutrient load of Lake Tahoe (CA-NV). Water Resour. Res. 30, 2207-2216.

Johansen, M.P., Hakonson, T.E., Breshears, D.D., 2001. Post-fire runoff and erosion from rainfall simulations: contrasting forests with shrublands and grasslands. Hydrol. Process. 15, 2953-2965.

Kane, J.M., Varner, J.M., Knapp, E.E., 2009. Novel fuelbed characteristics associated with mechanical mastication treatments in northern California and southwestern Oregon, USA. Int. J. Wildland Fire 18, 686-697.

Knapp, E.E., Keeley, J.E., 2006. Heterogeneity in fire severity within early season and late season prescribed burns in a mixed-conifer forest. Int. J. Wildland Fire 15, $37-45$.

Knapp, E.E., Keeley, J.E., Ballenger, E.A., Brennan, T.J., 2005. Fuel reduction and coarse woody debris dynamics with early season and late season prescribed fires in a Sierra Nevada mixed conifer forest. For. Ecol. Manage. 208, 383-397.

Knapp, E.E., Varner, J.M., Busse, M.D., Skinner, C.N., Shestak, C.J., 2011. Behaviour and effects of prescribed fire in masticated fuelbeds. Int. J. Wildland Fire 20, 932-945.

Levy, E.B., Madden, E.A., 1933. The point method of pasture analysis. New Zealand J. Agric. 46, 267-268.

MacDonald, L.H., Stednick, J.D., 2003. Forests and Water: A State-of-the-art Review for Colorado. Colorado Water Resources Research Institute Completion Report 196, Colorado State University, Fort Collins, Colorado.
Marcos, E., Tarrega, R., Luis-Calabuig, E., 2000. Comparative analysis of runoff and sediment yield with a rainfall simulator after experimental fire. Arid Soil Res. Rehabil. 14, 293-307.

Martin, R.E., Sapsis, D.B., 1992. Fires as agents of biodiversity: pyrodiversity promotes biodiversity. In: Proceedings of the Symposium on Biodiversity of Northwestern California, Wildland Resources Center Report NOP 29, University of California, Berkeley.

Mathys, N., Klotz, S., Esteves, M., Lapetite, J.M., 2005. Runoff and erosion in the Black Marls of the French Alps, observations and measurements at the plot scale. Catena 63, 261-281.

Mekbunditkul, T., Siripanich, P., 2010. Maximum likelihood estimation of parameters in Tobit-Piecewise Regression Model. In: Proceedings of the 6th IMT-GT Conference on Mathematics, Statistics and its Applications (ICMSA2010). Universiti Tunku Abdul Rahman, Kuala Lumpur, Malaysia.

Miller, C., Urban, D.L., 2000. Connectivity of forest fuels and surface fire regimes. Landscape Ecol. 15, 145-154.

Molinar, R.F., Galt, D., Holechek, J., 2001. Managing for mulch. Rangelands 23, 3-7.

Naslas, G.D., Miller, W.W., Gifford, G.F., Fernandez, G.C.J., 1994. Effects of soil type, plot condition, and slope on runoff and interrill erosion of two soils in the Lake Tahoe Basin. J. Am. Water Resour. Assoc. 30, 319-328.

Oswald, B.P., Davenport, D., Neuenschwander, L.F., 1999. Effects of slash pile burning on the physical and chemical soil properties of Vassar soils. J. Sustain. For. 8, 75-86.

Pannkuk, C.D., Robichaud, P.R., 2003. Effectiveness of needle cast at reducing erosion after forest fires. Water Resour. Res. 39 (12), 1333-1344.

Pennock, D., Yates, T., Braidek, J., 2008. Soil sampling designs. In: Patterson, G.T., Carter, M.R. (Eds.), Soil Sampling and Methods of Analysis, second ed. CRC Press, Boca Raton, Florida, pp. 25-37.

Quinn-Davidson, L., Varner, J.M., 2012. Impediments to prescribed fire across agency, landscape, and manager: an example from northern California. Int. J Wildland Fire 21, 210-218.

Robichaud, P.R., 1996. Spatially-varied Erosion Potential from Harvested Hillslopes after Prescribed Fire in the Interior Northwest. PhD Dissertation, University of Idaho, Moscow, Idaho, 219pp.

Robichaud, P.R., 2000. Fire effects on infiltration rates after prescribed fire in Northern Rocky Mountain forests, USA. J. Hydrol. 231, 220-229.

Robichaud, P.R., Waldrop, T.A., 1994. A comparison of surface runoff and sediment yields from low- and high-severity preparation burns. J. Am. Water Resour. Assoc. 30, 27-34.

Robichaud, P.R., Wagenbrenner, J.W., Brown, R.E., 2010. Rill erosion in natural and disturbed forests: 1 . Measurements. Water Resour. Res. 46, W10506. http://dx. doi.org/10.1029/2009WR008314.

Robichaud, P.R., Lewis, S.A., Wagenbrenner, J.W., Ashmun, L.E., Brown, R.E., 2013 Post-fire mulching for runoff and erosion mitigation Part I: effectiveness at reducing hillslope erosion rates. Catena 105, 75-92.

Rocca, M.E., 2009. Fine-scale patchiness in fuel load can influence initial post-fire understory composition in a mixed conifer forest, Sequoia National Park, California. Nat. Areas J. 29, 126-132.

Ryan, K.C., Knapp, E.E., Varner, J.M., 2013. Prescribed fire in North American forests and woodlands: history, current practice, and challenges. Front. Ecol. Environ. 11, e15-e24.

Safford, H.D., Schmidt, D.A., Carlson, C.H., 2009. Effects of fuel treatments on fire severity in an area of wildland-urban interface, Angora Fire, Lake Tahoe Basin, California. For. Ecol. Manage. 258 (5), 773-787.

Schoennagel, T., Veblen, T.T., Romme, W.H., 2004. The interaction of fire, fuels, and climate across Rocky Mountain forests. Bioscience 54, 661-676.

Scott, D.F., van Wyk, D.B., 1990. The effects of wildfire on soil wettability and hydrological behavior of an afforested catchment. J. Hydrol. 121, 239-256.

Sevink, J., Imeson, A.C., Verstraten, J.M., 1989. Humus form development and hillslope runoff and the effects of fire and management, under Mediterranean forest in NE Spain. Cateña 16, 461-475.

Shakesby, R.A., Coelho, C.D.A., Coelho, A.D., Ferreira, J.P.Terry., Walsh, R.P.D., 1993 Wildfire impacts on soil erosion and hydrology in wet Mediterranean forest Portugal. Int. J. Wildland Fire 3, 95-110.

Show, S.B., Kotok, E.I., 1924. The Role of Fire in California Pine Forests. U.S. Dept. of Agriculture, Dept. Bulletin No. 1294.

Silins, U., Stone, M., Emelko, M.B., Bladon, K.D., 2009. Sediment production following severe wildfire and post-fire salvage logging in the Rocky Mountain headwaters of the Oldman River Basin, Alberta. Catena 79, 189-197.

Stephens, S.L., McIver, J.D., Boerner, R.E.J., Fettig, C.J., Fontaine, J.B., Hartsough, B.R., Kennedy, P.L., Schwilk, D.W., 2012. The effects of forest fuel-reduction treatments in the United States. Bioscience 62 (6), 549-560. http://dx.doi.org/ 10.1525/bio.2012.62.6.6.

Stubblefield, A.P. Escobar, M.I. Larson, E.W 2006. Retention of suspended sediment and phosphorus on a freshwater delta, South Lake Tahoe, California. Wetlands Ecol. Manage. 14, 287-302.

Swift, T.J., Perez-Losada, J., Schlado, S.G., Reuter, J.E., Jassby, A.D., Goldman, C.R., 2005. Water clarity modeling in Lake Tahoe: linking suspended matter characteristics to Secchi depth. Aquat. Sci. 68, 1-15.

Taylor, A.H., 2004. Identifying forest reference conditions on cut-over lands, Lake Tahoe Basin, USA. Ecol. Appl. 14, 1903-1920.

Veira, D.C.S., Fernandez, C., Vega, J.A., Keizer, J.J., 2015. Does soil burn severity affect the post-fire runoff and interrill erosion response? A review based on metaanalysis of field rainfall simulation data. J. Hydrol. 523, 452-464. 
Vitorelo, B., Han, H.S., Elliot, W., 2011. Productivity and cost of integrated harvesting for fuel reduction thinning in mixed-conifer forest. For. Prod. J. 61 (8), 664-674.

Wade, D.D., Lunsford, J.D., 1989. A Guide for Prescribed Fire in Southern Forests. United States Department of Agriculture Forest Service, Technical Publication R8-TP11.

Wagenbrenner, J.W., Robichaud, P.R., 2014. Post-fire bedload sediment delivery across spatial scales in the interior western United States. Earth Surf. Proc. Land 39, 865-876.

Wagenbrenner, J.W., MacDonald, L.H., Rough, D., 2006. Effectiveness of three postfire rehabilitation treatments in the Colorado Front Range. Hydrol. Process. 20, 2989-3006.
Wainwright, J., Parsons, A.J., Abrahams, A.D., 2000. Plot-scale studies of vegetation, overland flow and erosion interactions: case studies from Arizona and New Mexico. Hydrol. Process 14, 2921-2943.

Wells, C.G., DeBano, L.F., Lewis, C.E., Fredriksen, R.L., Franklin, E.C., Froelich, R.C., Dunn, P.H., 1979. Effects of Fire on Soil. A State-of-Knowledge Review. USDA Forest Service, General Technical Report WO-7. Washington, DC.

Western Regional Climate Center, 2010. Western U.S. Climate Historical Summaries South Lake Tahoe, California. <http://www.wrcc.dri.edu/summary/tvl.ca.html> (accessed 19.01.12).

Zar, J.H., 1999. Biostatistical Analysis, fourth ed. Prentice-Hall, Englewood Cliffs, New Jersey. 